\title{
The Influence of Bisolbifit as a Fertilizer Modifier on the Oat Productivity
}

\author{
Galina Saidyasheva* \\ Ulyanovsk Research Institute of Agriculture - branch of SamSC RAS, 43315, Timiryazevsky, Ulyanovsk district, Ulyanovsk region, \\ Russia
}

\begin{abstract}
The purpose of the research was to study the effect of mineral fertilizers and biological product Bisolbi-fit as a modifier on the oat productivity. The studies were carried out on the experimental field of Ulyanovsk Research Institute of Agriculture, branch of Sam SC RAS. The soil was leached, heavy-clayey chernozem. The experiment was carried out in a 3-fold repetition by the method of split plots with a systematic arrangement of options. The total area of one plot was $145 \mathrm{~m} 2(5.8 \times 25)$, the accounting area was $100 \mathrm{~m} 2$ (4x25). The experiment scheme was as follows: 1. Control; 2. Presowing seed treatment with BisolbiFit in a dose of 400-600 g/t; 3. N15P15K15 in a dose of $15 \mathrm{~kg}$ ai/ha; 4. N15P15K15m in a dose of $15 \mathrm{~kg}$ ai/ha; $5.1 \frac{1}{2} \mathrm{~N} 15 \mathrm{P} 15 \mathrm{~K} 15 \mathrm{~m}$ in a dose of $7.5 \mathrm{~kg}$ a.i./ha. The effectiveness of the fertilizers was assessed during the cultivation of crops for three backgrounds: 1) zero - without fertilization; 2) NH4NO3m - treated with BisolbiFit in the dose of $40 \mathrm{~kg}$ a.i./ha; 3) NH4NO3 - in a dose of $40 \mathrm{~kg}$ ai/ha. It was established that the use of the microbiological preparation based on the Bacillus subtilis strain Ch-13, intended both for inoculation of seeds and use as a biomodifier of mineral fertilizers, had a positive effect on the crop structure, yield and grain quality. The most effective option was the one with Azofoska applied in a dose of $15 \mathrm{~kg}$ and modified with BisolbiFit at the rate of $4 \mathrm{~kg}$ per one ton of fertilizers on all the backgrounds. The use of BisolbiFit both for the pre-sowing seed treatment and treatment of mineral granules, increased the NPK payback by the yield gain.
\end{abstract}

\section{Introduction}

One of the most important tasks of agricultural production is to meet the needs of the population in food products. The basis for the yield of any agricultural crop is the technology of cultivation. The traditional technology involves the application of high doses of mineral fertilizers, chemical agents for pre-sowing protection of crops from diseases, experimental pests and elements of weeds [1-8]. All these measures increase and preserve yields of agricultural crops, but have side effects (contamination of soils, degradation of fertility) [9-11].

To reduce the need for grain fertilizers, increase the yield of crops, it is necessary to apply biologization and ecologization techniques, chemicals, biological products, whose biological basis is living microorganisms with beneficial properties [12].

If earlier microbiological preparations were used for pre-sowing seed treatment or plant treatment during the growing season [13] now they are applied to the mineral fertilizers which can decrease doses of fertilization and increase the coefficients of use of nutritional substances.

Today, in the world practice, there is a tendency to reduce the doses of mineral fertilizers; the integrated use of mineral fertilizers with agrotechnical techniques aimed at maintaining natural soil fertility and measures aimed at increasing the biodiversity of soil microflora, is widespread. Along with mineral fertilizers and chemical plant protection products, for economic and environmental reasons, it is proposed to widely use the possibilities of biological nitrogen fixation, biological plant protection products and microbiological fertilizers.

Biologization of mineral fertilizer granules with BisolbiFit is one of the most promising and effective ways to increase their efficiency. This method can increase the payback of mineral fertilizers by an increase in yield by $50-60 \%[15,16]$.

The purpose of the research was to assess the impact of mineral fertilizers and bisolbifit (Bacillus subtilis Ch-13) on the oat productivity.

\section{Materials and methods}

To achieve the goal, the two-factor experiment was conducted on the experimental field of Ulyanovsk Research Institute of Agriculture - a branch of the SamSC RAS. The land plot had heavy loamy leached (chernozem) soil. The results of the agrochemical maximum analysis are shown in Table 1: the soil had a neutral reaction, a high content of humus. The provision of the soil with mobile compounds of phosphorus and potassium was high. The experiment was carried out in a 3 -fold repetition by the method of split plots with a

\footnotetext{
Corresponding author: Galina_83@list.ru
} 
systematic arrangement of options. The total plot area was $145 \mathrm{~m}^{2}(5.8 \times 25)$, the accounting area was $100 \mathrm{~m}^{2}$ (4x25)

Table 1. Agrochemical characterization of the soil plot before the field experiment

\begin{tabular}{|c|c|c|c|c|c|}
\hline $\begin{array}{c}\text { Strength of } \\
\text { the horizon, } \\
\mathbf{s m}\end{array}$ & \multicolumn{5}{|c|}{ Indicator } \\
\cline { 2 - 6 } & $\begin{array}{c}\text { Humus, } \\
\mathbf{\%}\end{array}$ & $\mathbf{p H}_{\text {kcl }}$ & $\begin{array}{c}\mathbf{P}_{\mathbf{2}} \mathbf{O}_{\mathbf{5}}, \\
\mathbf{m g} / \mathbf{k g}\end{array}$ & $\begin{array}{c}\mathbf{K}_{\mathbf{2}} \mathbf{O}, \\
\mathbf{m g} / \mathbf{k g}\end{array}$ & $\begin{array}{c}\mathbf{N}_{\text {tot., }} \\
\mathbf{\%}\end{array}$ \\
\hline $0-30$ & 7.27 & 6.5 & $235-291$ & $95-138$ & 0,26 \\
\hline
\end{tabular}

Research objects were:

- mineral fertilizers: azofoska with $15 \%$ bisolbifit; ammonium nitrate $\mathrm{NH} 4 \mathrm{NO} 3$ with a nitrogen content of $34.4 \%$;

- BisolbiFit as a biomodified microbiological fertilizer and modifier of mineral grains, developed by the All-Russian Research Institute of Agricultural Microbiology on the basis of the Bacillus strain subtilis $\mathrm{H}-13$, used in the form of dry fine powder with $10^{6}$ $\mathrm{KOE} / \mathrm{g}$. The product consists of various strains of spore bacteria belonging to the genus Bacillus, living on the roots of healthy plants [16].

- modified mineral fertilizers based on the azofoska (N15P15K15m; 1/2 N15P15K15m) and ammonium nitrate (modifier $\mathrm{NH} 4 \mathrm{NO} 3 \mathrm{~m}$ ), whose granules were modified with BisolbiFit $(4 \mathrm{~kg} / \mathrm{t})$;

- agricultural crop: spring oats Rysak. Mid-season. The vegetation period is 78-95 days. addiction A type of mutic. Resistant to lodging. High drought resistance. Awnless. The grain is white, the mass of 1000 grains is $32-39 \mathrm{~g}$. The protein content is $12.4-14.9 \%$. The grain unit is $450-530 \mathrm{~g} / \mathrm{l}$. The filthiness is 24-28\%. Moderately resistant to head smut. Moderately susceptible to crown rust.

Crop rotation: grain-fallow with alternating crop yields: pure fallow - winter wheat - spring wheat barley - oats.

The scheme included the following options:

1. Control (without fertilizers); 2. Presowing treatment with Bisolbifit in a dose of 400-600 g/t; 3. Adding to Azophoska in a dose of $15 \mathrm{~kg}$ a.i./ha (N15P15K15); 4. Introduction of Azofoska treated with Bisolbifit (N15P15K15m) in a dose of $15 \mathrm{~kg}$ ai/ha; 5. Application of a half dose of azofoska treated with Bisolbifit ( $1 / 2$ application of N15P15K15m) in a dose of $7.5 \mathrm{~kg} \mathrm{a.i} / \mathrm{ha}$.

The effectiveness of mineral biomodified fertilizers and BisolbiFit was assessed for 3 backgrounds:

- background 1 - zero (control);

- background 2 - ammonium nitrate treated with a biological product in a dose of $40 \mathrm{~kg}$ a.i/ha (NH4NO3m);

- background 3 - ammonium nitrate in a pure form in a dose of $40 \mathrm{~kg}$ a.i/ha (NH4NO3).

Field experiments, sample analysis (soil, plant) were carried out according to GOST and methodological recommendations.

The following observations, records and analyzes were carried out: the content (agrochemical characteristics of the experimental site) of: humus according to Tyurin in the modification of TsINAO (GOST 26213-91); total nitrogen according to Kjeldahl (GOST 26107-84); mobile compounds of phosphorus and potassium according to the Chirikov's method in the modification of TsINAO (GOST 26204-91); preparation of salt extract and determination of its $\mathrm{pH}$ by the CINAO method (pHKCl) (GOST 26483-85); hydrolytic acidity according to Kappen as modified by ZINAO (GOST 26212-91); the sum of absorbed bases according to Kappen-Gilkovits (GOST 27821-88).

Analysis of the quality of oat grain: crude protein recalculated Ntot. $\times 5.7$; determination of the grain unit (GOST 10840-64); determination of the mass of 1000 grains (GOST 10842-89); determination of filminess (GOST 10843-76). Determination of the yield structure by the method of the State Variety Testing (1983). The crop accounting was carried out by the method of mechanized harvesting with subsequent conversion to the standard moisture content and purity by the continuous method.

The payback $(\mathrm{Pb})$ of fertilizers was calculated for the value of a productive increase by formula:

$$
\mathrm{Pb}=\mathrm{Yi} / \mathrm{D} \text {, }
$$

where $\mathrm{Yi}$ is the yield increase, $\mathrm{kg} / \mathrm{ha}$; D is the dose of application of the mineral fertilizer, $\mathrm{kg} / \mathrm{ha}$.

Statistical analysis. The experimental data were subjected to mathematical processing by the methods of dispersion and correlation-regression according to the method by B.A. Dospekhov (1985) [17]. Statistical processing of the results of field experiments was carried out in AGROS 2.06.

\section{Results}

The results of studies on the influence of mineral fertilizers and BisolbiFit (Bacillus subtilis Ch-13) on the oat productivity are presented in Tables 2-3 and Figures 1-3.

The yield was in direct linear dependence on the elements of the yield structure (Fig. 1).

Productivity of oats with the use of mineral fertilizers and BisolbiFit is shown in Figure 2.

The main elements of the structure that determine the level of productivity of oats include the productive stalk, the preservation of plants before harvesting, the mass of grain in a panicle, the mass of 1000 grams of grain, the number of grains in a panicle. The data in Table 2 indicate that the introduction of BisolbiFit in addition to mineral fertilizers had a positive effect on the structural indicators of oats.

According to Table 3, the fertilizers contributed to an increase in the yield had a positive effect on the quality indicators of oats.

The payback of fertilizers as an increase in the yield of oats is shown in Figure 3. 


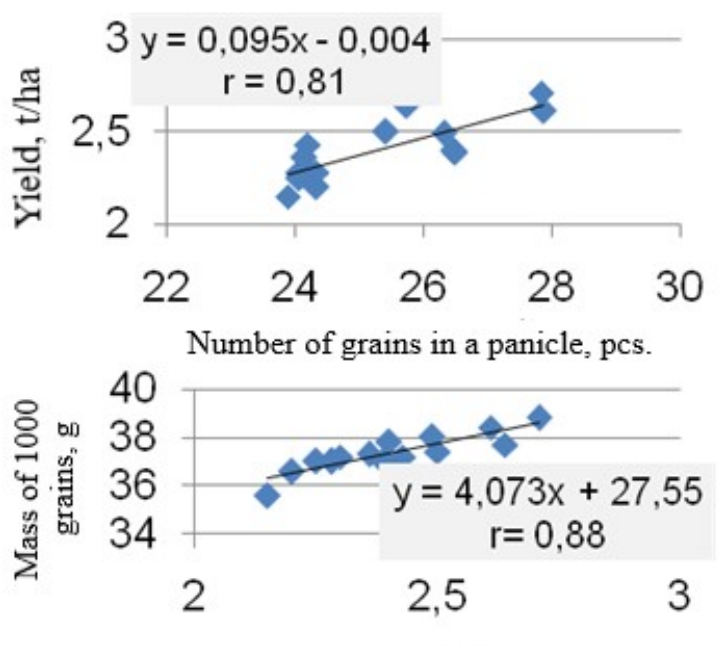

Yield, t/ha
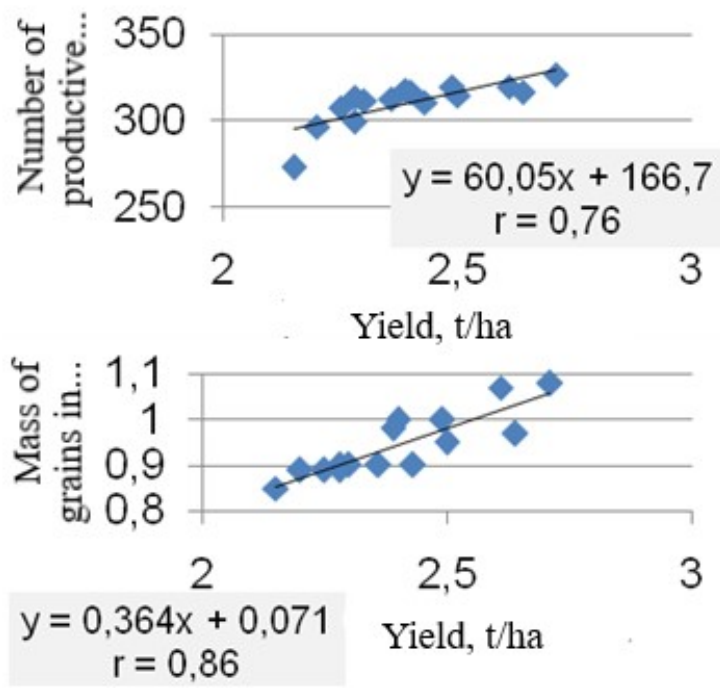

Fig. 1. Dependence of the oat yield on the crop structure when using mineral fertilizers and BisolbiFit, 2016-2018.

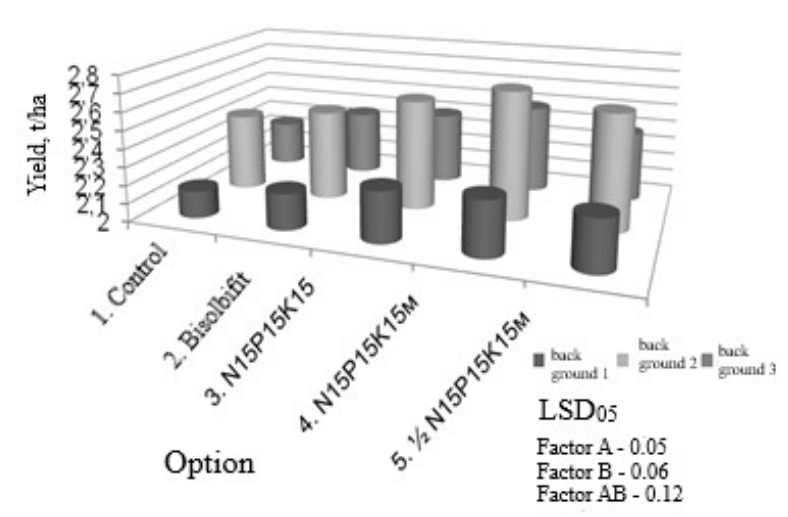

Fig. 2. The oat yield of with the use of mineral fertilizers and BisolbiFit for 3 years
Table 2. Elements of the oat yield structure depending on the application of mineral fertilizers and BisolbiFit, average for 3 years

\begin{tabular}{|c|c|c|c|c|c|}
\hline 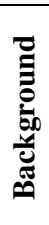 & 苛 & 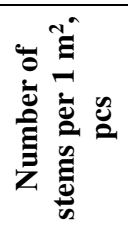 & 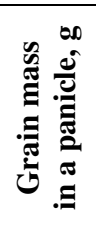 & 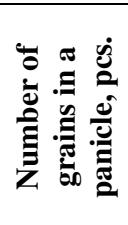 & 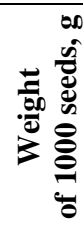 \\
\hline \multirow{6}{*}{$\stackrel{\circ}{\stackrel{\Xi}{N}}$} & 1 & 273 & 0,85 & 23,9 & 35,6 \\
\hline & 2. & 297 & 0,89 & 24,3 & 36,6 \\
\hline & 3. & 300 & 0,90 & 24,3 & 37,0 \\
\hline & 4. & 312 & 0,90 & 24,2 & 37,2 \\
\hline & 5. & 314 & 0,89 & 24,0 & 37,0 \\
\hline & av & 299 & $\mathbf{0 , 8 9}$ & 24,1 & 36,7 \\
\hline \multirow{6}{*}{ 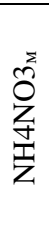 } & 1. & 311 & 0,90 & 24,2 & 37,2 \\
\hline & 2. & 315 & 0,95 & 25,4 & 37,4 \\
\hline & 3. & 320 & 1,07 & 27,8 & 38,4 \\
\hline & 4. & 327 & 1,08 & 27,8 & 38,8 \\
\hline & 5. & 317 & 0,97 & 25,7 & 37,7 \\
\hline & av & 318 & 0,99 & 26,2 & 38,0 \\
\hline \multirow{6}{*}{ 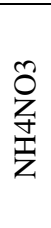 } & 1. & 308 & 0,89 & 24,1 & 37,0 \\
\hline & 2. & 313 & 0,90 & 24,1 & 37,3 \\
\hline & 3. & 317 & 1,0 & 26,5 & 37,8 \\
\hline & 4. & 320 & 1,0 & 26,3 & 38,0 \\
\hline & 5. & 318 & 0,98 & 26,5 & 37,0 \\
\hline & $\mathbf{A v}$ & 315 & 0,95 & 25,5 & 37,4 \\
\hline
\end{tabular}

* 1. Control; 2. BisolbyFit; 3. N15P15K15; 4. N15P15K15m; $5.1 / 2 \mathrm{~N} 15 \mathrm{P} 15 \mathrm{~K} 15_{\mathrm{m}}$

Table 3. Grain quality with the use of mineral fertilizers and BisolbiFit, average over 3 years

\begin{tabular}{|c|c|c|c|c|c|c|}
\hline \multirow{2}{*}{ Indicator } & \multirow{2}{*}{ Background } & \multicolumn{5}{|c|}{ Option } \\
\cline { 2 - 7 } & & $\mathbf{1}^{*}$ & $\mathbf{2}^{*}$ & $\mathbf{3}^{*}$ & $\mathbf{4}^{*}$ & $\mathbf{5}^{*}$ \\
\hline \multirow{3}{*}{ Protein, \% } & $1^{*}$ & 12,4 & 12,1 & 11,8 & 11,5 & 11,6 \\
\cline { 2 - 7 } & $2^{* *}$ & 12,0 & 12,0 & 11,6 & 11,3 & 11,3 \\
\cline { 2 - 7 } & $3^{* *}$ & 12,1 & 12,0 & 11,6 & 11,5 & 11,6 \\
\hline Grain unit, g/l & $1^{* *}$ & 470 & 472 & 480 & 478 & 474 \\
\cline { 2 - 7 } & $2^{* *}$ & 478 & 482 & 488 & 490 & 488 \\
\cline { 2 - 7 } & $3^{* *}$ & 474 & 478 & 488 & 486 & 484 \\
\hline Filminess, \% & $1^{* *}$ & 33,1 & 33,0 & 29,6 & 27,3 & 30,0 \\
\cline { 2 - 7 } & $2^{* *}$ & 30,0 & 29, & 27,0 & 25,8 & 27,2 \\
\cline { 2 - 7 } & $3^{* *}$ & 31,5 & 29,0 & 27,6 & 27,0 & 28,0 \\
\hline
\end{tabular}

* 1. Control; 2. BisolbyFit; 3. N15P15K15; 4. N15P15K15 5. $1 / 2 \mathrm{~N} 15 \mathrm{P} 15 \mathrm{~K} 15_{\mathrm{M}}$

** Background 1 - zero: Background $2-\mathrm{NH}_{4} \mathrm{NO}_{3}$;

Background 3 - NH4NO3

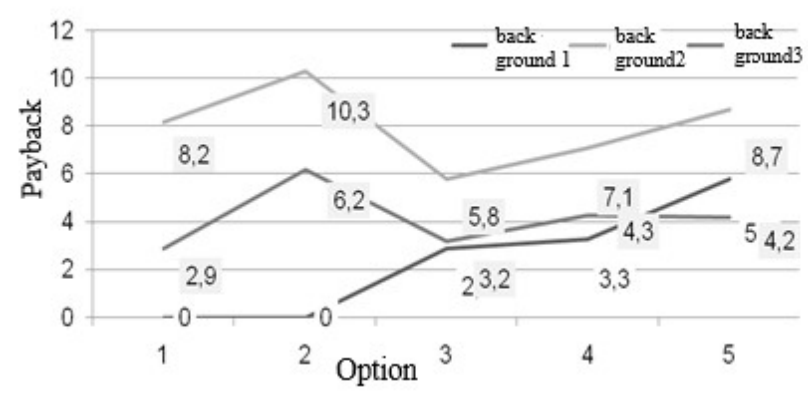

Fig. 3. Payback of fertilizers by an increase in the yield of oats, $\mathrm{kg} / \mathrm{kg}$ (average over 3 years) 


\section{Discussion}

Crop structure elements. On average, the number of stems increased from 273 to $327 \mathrm{pcs} / \mathrm{m}^{2}$. In the control option, the number of stems varied from 273 to $311 \mathrm{pcs} / \mathrm{m}^{2}$; in the option with BisolbiFit, it varied from 297 to $315 \mathrm{pcs} / \mathrm{m}^{2}$; in the option with with Azophoska in pure form (N15P15K15), it varied in the range of $300-320 \mathrm{pcs} / \mathrm{m} 2$; in the option with biomodified azofoska (N15P15K15m), it varied from 312 to $327 \mathrm{pcs} / \mathrm{m}^{2}$ and in the option with half dose of biomodified azofoska $(1 / 2 \mathrm{~N} 15 \mathrm{P} 15 \mathrm{~K} 15 \mathrm{~m})$, it varied from 314 to $317 \mathrm{pcs} / \mathrm{m}^{2}$.

In all control backgrounds, the smallest number of grains in the panicle was observed: 23.9, 24.1, 24.2 pcs. In the option with azofoska, both in pure form and biomodified with BisolbiFit (N15P15K15, N15P15K15m, 1/2 N15P15K15m), the highest yield of grain was obtained In the option with BisolbiFit (presowing seed treatment), the number of grains in the panicle changed from 24.1 to 25.4 pcs (Table 2).

The mass of 1000 seeds determines the size of nutrients and the greater output of a commercial product. bisolbifit The studies established that the weight of 100 oat seeds was determined, both by weather conditions and the biological product BisolbiFit.

For the years of research, the weight of 1000 seeds increased from 35.6 to $38.8 \mathrm{~g}$. Fertilization had a positive effect on the indicator, increasing its value by $0.8-1.6 \mathrm{~g}$.

The fertilization (NH4NO3m, NH4NO3) contributed to an increase of the number of productive stems by $16-19 \mathrm{pcs} / \mathrm{m}^{2}$; mass of grain in a panicle by $0.06-0.1 \mathrm{~g}$; the number of grains in a panicle by 1.4-2.1 pcs.; the weight of 1000 seeds - by $0.7-1.3 \mathrm{~g}$.

Among the types and doses of fertilizers, the highest value of structural parameters of the oat yield was observed in the option with biomodified Azofoski (N15P15K15m).

Between the elements of the crop structure and the yield, there is a direct relationship.

On the basis of the correlation analysis, the positive correlation was established: the number of productive stems - yield; grain mass per panicle - yield; mass of 1000 seeds - yield; the number of grains per panicle - yield; the coefficient was $\mathrm{r}=0.76, \mathrm{r}=0.86, \mathrm{r}=0.88, \mathrm{r}=0.81$, respectively.

Productivity. It is known that the yield of grain is the main indicator in assessing the techniques for cultivating plants. It depends on the growing conditions. In the process of growth and development of plants, requirements are imposed on the external environment associated with the grain unit and intensity of physiological and biochemical mineral processes. The use of mineral fertilizers is one of the most effective and fast-acting factors increasing the yield of oats. In the last decade, a promising direction is the use of microbiological drugs, which also contribute to an increase in the grain productivity [16].

In the 2016-2018 studies, it was found that the introduction of mineral fertilizers and BisolbiFit had a positive effect on the yield of oats (Fig. 2). On average, the oat yield increased from 2.15 to $2.71 \mathrm{t} / \mathrm{ha}$. The application of ammonium nitrate as a background fertilizer increased the yield of oats to $2.38-2.57 \mathrm{t} / \mathrm{ha}$.

The yield obtained was obtained in the control option. The yield of grain reached 2.15 studied $t / h a$ in the control option; in the option with the application of NH4NO3m, it was 2.43 dose t/ha and with the application of NH4NO3 $-2.25 \mathrm{t} / \mathrm{ha}$. The introduction of azofoska in its pure form increased the yield by 0.13 , 0.18 and 0.15 t/ha.

The biomodification of mineral fertilizers (N15P15K15m) contributed to the further growth of the yield. The half dose of biomodified Azofoska $(1 / 2 \mathrm{~N} 15 \mathrm{P} 15 \mathrm{~K} 15 \mathrm{~m})$ increased the grain yield by $0.13 \mathrm{t} / \mathrm{ha}$ (background 1); by 0.49 indicators t/ha (background 2); and by $0.24 \mathrm{t} / \mathrm{ha}$ (background 3 ).

The maximum yield was obtained by the introduction of ammonium (NH4NO3m dose) in a dose of $40 \mathrm{~kg}$ ai/ha treated with BisolbiFit ; the average yield was $2.57 \mathrm{t} / \mathrm{ha}$.

Grain quality. The fertilizers contributed to the increase in the yield had a positive influence on quality indicators of oat grain. In all the options, the content of protein was $12.4,12.0,12.1 \%$.

The grain unit significantly increased under the influence of the fertilizers (mineral and microbiological) applied individually or in combination with ammonium nitrate. It changed from 466 to $490 \mathrm{~g} / \mathrm{l}$. The grain unit increased by $2-18 \mathrm{~g} / \mathrm{l}$.

The highest value of $490 \mathrm{~g} / \mathrm{l}$ was obtained in option 4 (N15P15K15m), when modified ammonium nitrate was introduced for the pre-sowing cultivation.

An increase in the oat yield was accompanied by a decrease in the protein content from 11.3 to $12.4 \%$. The average protein content was $11.8 \%$.

The filmness is the content of the chaffy casing expressed through the ratio of film weight to the average grain weight. Under the influence of mineral fertilizers, a decrease in filmness was observed. The smallest percentage of filminess was observed in the option with the aplication of N15P15K15 - 27.3, 25.8, 27.0\%, which is $4.2-5.8 \%$ lower than in the control option. The pre-sowing treatment with the biological product did not have a significant effect on this indicator. The maximum value was observed in the control options: $33.1,30.0$, $31.5 \%$.

Payback. When the fertilizers were applied, the payback ranged from 2.9 to $10.3 \mathrm{~kg}$ of grain per $\mathrm{kg}$ of the fertilizers. The presowing treatment of seeds with Bacillus subtilis Ch-13 increased the fertilization payback to $6.2-10.3 \mathrm{~kg} / \mathrm{kg}$.

Against the background without fertilizer, the greatest payback of $1 \mathrm{~kg} \mathrm{NPK}$ was obtained in the option with azophoska modified with bisolbifit in a dose of $7.5 \mathrm{~kg}$ a.i. $/ \mathrm{ha}-5.8 \mathrm{~kg} / \mathrm{kg}$; the smallest payback was obtained in the option with pure azophoska in a dose of $16.0 \mathrm{~kg} \mathrm{ai} / \mathrm{ha}(2.9 \mathrm{~kg} / \mathrm{kg})$.

The maximum payback of $1 \mathrm{~kg}$ NPK was obtained with the introduction of biomodified ammonium nitrate in combination with fertilizers that were used for sowing; it varied from 8.2 to $10.3 \mathrm{~kg} / \mathrm{kg}$.

The introduction of ammonium nitrate in a pure form (NH4NO3) increased the productivity of oats by $6.3 \%$ 
in relation to the zero option ; as a result, the payback of $1 \mathrm{~kg}$ NPK decreased by 2.9-6.2 kg/kg (Fig. 3).

BisolbiFit used for both the pre-sowing seed treatment and treatment of granules of mineral fertilizers increased the payback of $1 \mathrm{~kg}$ NPK and the yield.

However, the inoculation of oat seeds with BisolbiFit turned out to be the most payback technique, which can be compared with biomoodified Azophoska.

\section{Conclusion}

1. The indicators of the elements of the oat yield structure were higher with the application of ammonium treated with Bacillus subtilis Ch-13; the number of productive stems increased by $6,4 \%$; the weight of grain per panicle increased by $11.2 \%$, the amount of grains increased by $8.7 \%$ and the weight of 1000 seeds increased by $3.4 \%$. The maximum yield varied from 2.43 to $2.71 \mathrm{t} / \mathrm{ha}$; an increase was $3.0-11.6 \%$.

2. The fertilizers had a positive effect on the qualitative oat indicators. The relationship between the mass of 1000 seeds and the content of protein was negative $(\mathrm{r}=-0.76)$. Protein content varied from 11.3 to $12.4 \%$. The grain unit content increased by $2-20 \mathrm{~g} / \mathrm{l}$ $(0.4-4.3 \%)$, the filminess decreased by $0.1-7.3 \%$.

3. The oat grain grown with the addition of ammonia in a dose of $16 \mathrm{~kg}$ ai/ha modified with BisolbiFit, turned out to be negative provided the maximum yield.

4. BisolbiFit used for both pre-sowing treatment of seeds and treatment of granules of mineral fertilizers increased the payback of $1 \mathrm{~kg} \mathrm{NPK}$.

\section{References}

1. J.K. Patel, G. Archana, Plant and Soil (2017)

2. K.A Tsukanova., V.K. Chebotar, T.N. Bibikova, J.J.M. Meyer, South Afric. J. of Botany (2017)

3. A.A. Zavalin, O.A. Sokolov, N.Ya. Shmyreva, S.V. Lukin, Amazonia investiga (2019)

4. A.A. Zavalin, L.S. Chernova, S.N. Sapozhnikov, A.A. Kovalenko, Russ. Agricult. Sci. (2020)

5. A.Kh. Kulikova, G.V. Saidyasheva, The effectiveness of biomodified mineral fertilizers in the cultivation of agricultural crops on the chernozems of the forest-steppe of the Volga region, Bull. of the Ulyanovsk State Agricult. Acad., 4(52), 73-79 (2020)

6. S.N. Nikitin, Evaluation of the effectiveness of biological products in the biological product in the
Middle Volga region (Venets, Ulyanovsk, 2014), $135 \mathrm{p}$.

7. S.N. Nikitin, S.A. Zakharov, Crop rotation productivity and economic efficiency when using various types of organic fertilizers, diatomite and biological products, Int. Agricul. J., 1, 40-44 (2016)

8. S.A. Shafran, T.M. Dukhanina, The value of complex agrochemical soil cultivation in increasing the efficiency of the use of nitrogen fertilizers for wheat, Agrochem., 11, 21-30 (2017)

9. Yu.A. Gavrilova, The effectiveness of the maximum application of processing complex biomodified under barley on the pattern of sod-podzolic main light loamy soil, Cand. dissrertation thesis (Moscow, 2018), 24 p.

10. A.A. Alferov, L.S. Chernov, A.A. Zavalin, V.K. Chebotar, The effectiveness of application of endophytic experience of biological products and the content of nitrogen fertilizers, Bull. of the Russ. Agricult. Sci., 5, 21-24 (2017)

11. R.C. Kasana, R. Salwan, S. Dhar, S. Dutt, A. Gulati, Curr. Microbiol. (1985)

12. G. Sajdiasheva, A. Kulikova, A. Laschenkov, S.N. Nemtsev, Influence of mineral and modified fertilizers on oat yield, BIO Web of Conf., 17 (2020)

13. H. Junge, P. Krebs, M. Kilian, PflanzenschutzNachrichten Bayer, 1 (2000)

14. M. Kilian, U. Steiner, B. Krebs, H. Junge, G. Schmiedeknecht, R. Hain, PflanzenschutzNachrichten Bayer, 1, 72-93 (2000)

15. M. Kilian, U. Steiner, B. Krebs, H. Junge, G. Schmiedeknecht, R. Hain, FZB24® Bacillus Subtilis-Mode of Action of a Microbial Agent Enhancing Plant Vitality, PflanzenschutzNachrichten Bayer, 1, 72-93 (2000)

16. A.A. Zavalin, A.M. Nakaryakov, The effectiveness of biological products in the sowing of winter wheat on light gray forest soil, Agricult., 1, 27-30 (2021)

17. Method of producing biofertilizers, RF patent for invention, No. 2241692 (Moscow, 2004)

18. A.A. Zavalin, L.V. Vinogradova, T.M. Dukhanina, A.V. Vaulin, M.V. Chistotin, D.B. Sologub, M. Gabibov, P.V. Lekomtsev, A.V. Pasynkov, Plant Microbial Interactions: Positive interactions in relation to crop production and utilization, Aspec. of Appl. Biol., 63 (2001)

19. B.A. Dospekhov, Field experiment technique (Moscow, 1985), 351 p. 